\title{
An empirical study on measuring the effect of layoff on job satisfaction and employee commitment: A case study of detergent producer unit
}

\author{
Abolfazl Tajzadeh-Namin*
}

Faculty of Management and Accounting, Allameh Tabataba'i University, Tehran, Iran

\begin{tabular}{|c|c|}
\hline A R T I C L E I N F O & A B S T R A C T \\
\hline $\begin{array}{l}\text { Article history: } \\
\text { Received June 25, } 2011 \\
\text { Received in Revised form } \\
\text { August, } 28,2011 \\
\text { Accepted } 3 \text { September } 2011 \\
\text { Available online } \\
5 \text { September } 2011 \\
\text { Keywords: } \\
\text { Job satisfaction } \\
\text { Employee commitment } \\
\text { Employee reduction }\end{array}$ & $\begin{array}{l}\text { One of the necessary actions in many organizations is to reduce the number of workers in an } \\
\text { attempt to restructure business activities. However, layoff could have negative consequences } \\
\text { since many employees may decide to leave since they lose their tolerance. The layoff must be } \\
\text { accompanied with some supportive plans to reduce stress among the remaining workers and } \\
\text { increase their commitment for long-term work. The present study of this paper considers the } \\
\text { effects of layoff on job satisfaction and commitment among the remaining employees of a } \\
\text { detergent producer unit. The results indicate that a good supportive program including wage } \\
\text { increase, family support, health care plans, etc. could significantly improve employee long-term } \\
\text { commitments and it leads to job satisfaction. }\end{array}$ \\
\hline
\end{tabular}

\section{Introduction}

During the past few decades, many business units have used different layoff plans to restructure business units and develop products with lower cost. The increase in competitions among international firms has motivated many to use technology-based equipments in an attempt to reduce workforces. An immediate consequence of layoff is that the remaining workers may lose their confidence and decide to plan for other job opportunities. Therefore, organizations need to provide supportive plans to increase workers' motivation by providing additional benefit packages such as healthcare, dental plan, wage increase, recreational plan, etc. (Wiener, 1982). There are different studies to measure the relative importance of layoff of workers' confidence, loyalty, etc.

Mckee-Ryan and Kinicki (2002) believe a mass layoff not only hurt people who lose their jobs but also it could have some social consequences. An immediate layoff decision is to expect the remaining workers to work harder and produce more products, which could put more pressure and increase their working stress (McKinley et al., 1995). The ultimate objective of layoff could be to increase profitability through reducing direct payment but the layoff could lead to opposite results

* Corresponding author. Fax: + 0982144129397

E-mail addresses: tajzadehnamin@yahoo.com (A. Tajzadeh-namin) 
since workers may not work as well as they used to do (Rigby, 2002). Any resistance on behalf of the employees could initiate such negative consequences (Beam, 1997). According to Millward and Brewerton (2002), workers believe terminating a permanent contract offends them and they expect managers to be faithful to their long-term contracts. Shah (2000) reports that any successful downsizing program must be accompanied with better benefit packages, which includes better features. Prahalad and Hamel (1990) recommend special attention on maintaining human resources since they are considered as intangible assets. There are different plans to measure the effects of supportive plans on remaining employees (Hoppock, 1935; McKinley et al., 1995, 2000; Greenhalgh et al., 1988; Baron, 1999; Seal \& Knight, 1988).

Shah (2000) measures the relationship between the impact of layoff on the remaining employees' job satisfaction and confidence. Fisher and White (2000) study the impact of layoff on social relationships. According to Wright and McMahan (1992), Wright and Snell (1998) and Hirschman (2001), it is important to find out the most important factors influencing employees' confidence when layoff happens. Mitchell and Lee (2001) explain that job satisfaction and confidence play vital role on keeping the remaining employees of any organizations. Meyer et al. (1991) discuss how to motivate the employee during the first year of employment. Cascio (1993), Sun and Yeh (1996) and McMaster (2002) report that the success of a business firm, which has recently reduced its stuff does not depend on increasing productivity but it depends on taking care of the remaining employees.

Naumann et al. (1995) propose some framework based on Eisenberger et al. (1990) to increase the remaining employees' confidence and job satisfaction. The framework suggests that a more supportive employee program could increase profitability and overall perception of company's infrastructure. Delery and Shaw (2001) report that employee motivation is considered as one of the most important factors for the success of business units. Herzberg (2003) studies various motivation techniques and their effects on the success of a company. Smith et al. (1969) is believed to be the first who introduced different techniques for increasing job satisfaction and Cameron (1994) introduces some techniques for a successful downsizing without losing employee job satisfaction. Brockner et al. (1997) perform a comprehensive study on what happens on the remaining employees when a layoff plan occurs.

The study of this paper presents an empirical investigation on the effect of workforce reduction on the remaining job satisfaction and confidence. This paper is organized as follows. We first present the proposed framework in section 2 and section 3 explains details of our analysis. Finally, concluding remarks are given at the end to summarize the contribution of this paper.

\section{The proposed framework}

In order to study the impact of different factors on job satisfaction and employee confidence when layoff happens we have designed a questionnaire using Likert scale (Likert, 1932). The study also uses principle component analysis with vertical rotation (Hair et al., 1998) on a questionnaire consists of 87 questions to reduce the number of items to 14 . We have removed those items whose reliability was below 0.50 . We finally remove 19 items and kept 68 questions, which were categorized into 10 different parts with $R^{2}=76.173$ and Cronbach Alpha (CA) (Cronbach, 1951) was calculated as 0.79. Table 1 summarizes ten different items.

\section{Table 1}

Characteristics of ten different items

\begin{tabular}{|c|c|c|c|c|c|c|c|c|c|c|}
\hline Item & $\begin{array}{l}\text { Management } \\
\text { style }\end{array}$ & $\begin{array}{l}\text { Work } \\
\text { identity }\end{array}$ & $\begin{array}{l}\text { Working } \\
\text { environment }\end{array}$ & $\begin{array}{l}\text { Job } \\
\text { promotion }\end{array}$ & $\begin{array}{l}\text { Employee } \\
\text { relationship }\end{array}$ & Security & Payment & Family & $\begin{array}{l}\text { Performance } \\
\text { measurement }\end{array}$ & Environment \\
\hline CA & 0.9278 & 0.9566 & 0.9599 & 0.9091 & 0.8892 & 0.9369 & 0.8915 & 0.7959 & 0.9232 & 0.9066 \\
\hline
\end{tabular}


As we can observe from Table 1 all items represent a reliable Cronbach Alpha and details of personal characteristics of the people who participated in our survey are given in Table 2.

Table 2

Personal characteristics of the participants

\begin{tabular}{llll}
\hline Variable & Item & $\mathrm{N}$ & $\%$ \\
\hline \multirow{3}{*}{ Job status } & The number of supervisor & 51 & 24.4 \\
& The number of non-supervisor & 149 & 71.3 \\
& No-information & 9 & 4.3 \\
\hline \multirow{5}{*}{ Job experience } & Less than 5 years & 0 & 0 \\
& 6-10 years & 30 & 14.3 \\
& 11-15 years & 98 & 46.9 \\
& 16 years or more & 71 & 34.0 \\
& No information & 10 & 4.8 \\
\hline \multirow{5}{*}{ Education } & Less than 12 years of educational level & 0 & 0 \\
& 12 years of educational level & 74 & 35.4 \\
& 14 years of educational level & 75 & 35.9 \\
& 16 years of educational level & 43 & 26.6 \\
& 18 years of educational level or more & 9 & 4.3 \\
& No information & 8 & 3.8 \\
\hline \multirow{5}{*}{ Age } & Less than 30 years & 2 & 1 \\
& Between 30 to 39 & 77 & 36.8 \\
& Between 40 to 49 & 102 & 48.8 \\
& 50 years or more & 19 & 9.1 \\
\hline
\end{tabular}

As we can observe from Table 2, most of the participants are from non-supervisory section with over 10 years of job experience. Over 70 percents of them have less than 14 years of educational background and they are mostly middle age people.

\section{Results}

This section summarizes details of our studies on the people who took part in our survey. Table 3 shows the summary of ten factors.

Table 3

The summary of the results

\begin{tabular}{lllllllllllc}
\hline Item & 1 & 2 & 3 & 4 & 5 & 6 & 7 & 8 & 9 & 10 & $\begin{array}{c}\text { Permanent } \\
\text { Commitment }\end{array}$ \\
\hline 1 & 1.000 & $0.532^{* *}$ & $0.551^{* *}$ & $0.551^{* *}$ & $0.393^{* *}$ & $0.528^{* *}$ & $0.528^{* *}$ & $0.451^{* *}$ & $0.636^{* *}$ & $0.615^{* *}$ & $0.287^{* *}$ \\
2 & $0.532^{* *}$ & 1.000 & $0.765^{* *}$ & $0.765^{* *}$ & $0.389^{* *}$ & $0.632^{* *}$ & $0.632^{* *}$ & $0.468^{* *}$ & $0.580^{* *}$ & $0.627^{* *}$ & $0.529^{* *}$ \\
3 & $0.551^{* *}$ & $0.765^{* * *}$ & 1.000 & 1.000 & $0.302^{* *}$ & $0.680^{* *}$ & $0.680^{* *}$ & $0.683^{* *}$ & $0.637^{* *}$ & $0.707^{* *}$ & $0.451^{* *}$ \\
4 & $0.527^{* *}$ & $0.643^{* *}$ & $0.743^{* *}$ & $0.743^{* *}$ & $0.331^{* *}$ & $0.558^{* *}$ & $0.558^{* *}$ & $0.544^{* *}$ & $0.656^{* *}$ & $0.644^{* *}$ & $0.389^{* *}$ \\
5 & $0.393^{* *}$ & $0.389^{* *}$ & $0.302^{* *}$ & $0.302^{* *}$ & 1.000 & $0.437^{* *}$ & $0.437^{* *}$ & $0.386^{* *}$ & $0.359^{* *}$ & $0.384^{* *}$ & $0.316^{* *}$ \\
6 & $0.528^{* *}$ & $0.632^{* *}$ & $0.558^{* *}$ & $0.558^{* *}$ & $0.437^{* *}$ & 1.000 & 1.000 & $0.596^{* *}$ & $0.629^{* *}$ & $0.627^{* *}$ & $0.431^{* *}$ \\
7 & $0.307^{* *}$ & $0.573^{* *}$ & $0.596^{* *}$ & $0.596^{* *}$ & $0.190^{* *}$ & $0.485^{* *}$ & $0.485^{* *}$ & $0.469^{* *}$ & $0.484^{* *}$ & $0.504^{* *}$ & $0.386^{* *}$ \\
8 & $0.451^{* *}$ & $0.648^{* *}$ & $0.544^{* *}$ & $0.544^{* *}$ & $0.386^{* *}$ & $0.596^{* *}$ & $0.596^{* *}$ & $1.000^{* *}$ & $0.572^{* *}$ & $0.626^{* *}$ & $0.469^{* *}$ \\
9 & $0.636^{* *}$ & $0.580^{* *}$ & $0.656^{* *}$ & $0.656^{* *}$ & $0.659^{* *}$ & $0.629^{* *}$ & $0.629^{* *}$ & $0.572^{* *}$ & 1.000 & $0.637^{* *}$ & $0.366^{* *}$ \\
10 & $0.615^{* *}$ & $0.627^{* *}$ & $0.644^{* *}$ & $0.644^{* *}$ & $0.384^{* *}$ & $0.627^{* *}$ & $0.627^{* *}$ & $0.626^{* *}$ & $0.637^{* *}$ & 1.000 & $0.330^{* *}$ \\
Permanent & $0.287^{* *}$ & $0.529^{* *}$ & $0.451^{* *}$ & $0.451^{* *}$ & $0.316^{* *}$ & $0.431^{* *}$ & $0.431^{* *}$ & $0.469^{* *}$ & $0.366^{* *}$ & $0.330^{* *}$ & 1.000 \\
Commitment & & & & & & & & & & &
\end{tabular}

1: Management style, 2: Work identity, 3: Working environment, 4: Job promotion, 5: Employee relationship, 6: Security, 7: Payment, 8: Family, 9: Performance measurement, 10: Environment

As we can observe from the results of Table 3, different levels of people have various levels of job satisfaction on their jobs. Therefore, people may have different perceptions on their working environment based on what they experienced. As a result, any human resource development must be in accordance with good knowledge about population. We could also expect different long-term commitment among people with various educational background, supervision status and age. Next, 
we use some dummy variables representing these items to measure the relative influence of these components. The case study that we did our survey incorporated three subdivisions A, B and C. Most employees who participated in our survey were from these three units. However, two groups from administrative (D) and service (E) sections were working outside the units. We also considered employee in supervision position level (SL) and those who were not (NSL). Table 4 shows the details of our analysis on the relationship between seven variables A, B, C, D, E, SL and NSL and 10 components of commitments. Table 5 summarizes the results of our survey for permanent commitment.

Table 4

Principle component analysis among different independent items

\begin{tabular}{|c|c|c|c|c|c|c|c|c|c|c|}
\hline \multirow[b]{3}{*}{ Variable } & \multicolumn{10}{|c|}{ Commitment } \\
\hline & \multicolumn{2}{|c|}{1} & \multicolumn{2}{|c|}{2} & \multicolumn{2}{|c|}{3} & \multicolumn{2}{|c|}{4} & \multicolumn{2}{|c|}{5} \\
\hline & SD & $\mathrm{F}$ & SD & $\mathrm{F}$ & SD & $\mathrm{F}$ & SD & F & SD & $\mathrm{F}$ \\
\hline A & $\begin{array}{c}3.067 \\
(0.722)\end{array}$ & 2.214 & $\begin{array}{c}2.76 \\
(0.574)\end{array}$ & 2.178 & $\begin{array}{c}2.626 \\
(0.606)\end{array}$ & 0.819 & $\begin{array}{c}2.560 \\
(0.524)\end{array}$ & 2.012 & $\begin{array}{c}3.177 \\
(0.540)\end{array}$ & $4.026^{*}$ \\
\hline B & $\begin{array}{c}2.496 \\
(0.487)\end{array}$ & & $\begin{array}{c}3.201 \\
(0.510)\end{array}$ & & $\begin{array}{c}2.917 \\
(0.627)\end{array}$ & & $\begin{array}{c}0.831 \\
(0.642)\end{array}$ & & $\begin{array}{c}3.630 \\
(0.512)\end{array}$ & \\
\hline $\mathrm{C}$ & $\begin{array}{c}3.366 \\
(0.819)\end{array}$ & & $\begin{array}{c}0.927 \\
(0.722)\end{array}$ & & $\begin{array}{c}2.706 \\
(0.820)\end{array}$ & & $\begin{array}{c}2.449 \\
(0.820)\end{array}$ & & $\begin{array}{c}3.421 \\
(0.580)\end{array}$ & \\
\hline D & $\begin{array}{c}3.334 \\
(0.835)\end{array}$ & $11.492^{* *}$ & $\begin{array}{c}0.789 \\
(0.687)\end{array}$ & $30.051^{* *}$ & $\begin{array}{c}2.552 \\
(0.795)\end{array}$ & $26.382^{* *}$ & $\begin{array}{c}2.406 \\
(0.793)\end{array}$ & $8.192^{* * *}$ & $\begin{array}{c}3.340 \\
(0.595)\end{array}$ & $8.185^{* *}$ \\
\hline $\mathrm{E}$ & $\begin{array}{c}3.655 \\
(0.544)\end{array}$ & & $\begin{array}{c}3.384 \\
(0.531)\end{array}$ & & $\begin{array}{c}3.157 \\
(0.528)\end{array}$ & & $\begin{array}{c}2.765 \\
(0.680)\end{array}$ & & $\begin{array}{c}3.603 \\
(0.492)\end{array}$ & \\
\hline SL & $\begin{array}{c}3.603 \\
(0.822)\end{array}$ & $7.402^{* *}$ & $\begin{array}{c}3.275 \\
(0.710)\end{array}$ & $15.495^{* *}$ & $\begin{array}{c}3.116 \\
(0.672)\end{array}$ & $19.739^{* *}$ & $\begin{array}{c}2.789 \\
(0.797)\end{array}$ & $10.345^{* *}$ & $\begin{array}{c}3.500 \\
(0.682)\end{array}$ & $1.997^{*}$ \\
\hline \multirow[t]{2}{*}{ NSL } & $\begin{array}{c}3.261 \\
(0.757)\end{array}$ & & $\begin{array}{c}2.826 \\
(0.667)\end{array}$ & & $\begin{array}{c}2.574 \\
(0.774)\end{array}$ & & $\begin{array}{c}2.389 \\
(0.748)\end{array}$ & & $\begin{array}{c}3.368 \\
(0.532)\end{array}$ & \\
\hline & \multicolumn{8}{|c|}{$\begin{array}{l}\text { Commitment } \\
8\end{array}$} & \multicolumn{2}{|c|}{10} \\
\hline Variable & SD & $\mathrm{F}$ & SD & $\mathrm{F}$ & SD & $\mathrm{F}$ & SD & $\mathrm{F}$ & SD & $\mathrm{F}$ \\
\hline A & $\begin{array}{c}3.169 \\
(0.575)\end{array}$ & 2.050 & $\begin{array}{c}2.656 \\
(0.324)\end{array}$ & 1.671 & $\begin{array}{c}3.056 \\
(0.587)\end{array}$ & 0.971 & $\begin{array}{c}2.917 \\
(0.518\end{array}$ & 0.677 & $\begin{array}{c}2.677 \\
(0.760)\end{array}$ & 2.042 \\
\hline B & $\begin{array}{c}3.622 \\
10.626\end{array}$ & & $\begin{array}{c}3.059 \\
(0.709)\end{array}$ & & $\begin{array}{c}3.097 \\
(0.692)\end{array}$ & & $\begin{array}{c}2.097 \\
(0.520)\end{array}$ & & $\begin{array}{c}3.185 \\
(0.786)\end{array}$ & \\
\hline $\mathrm{C}$ & $\begin{array}{l}3.208 \\
(0.912\end{array}$ & & $\begin{array}{c}2.675 \\
(0.884)\end{array}$ & & $\begin{array}{c}3.239 \\
(0.770)\end{array}$ & & $\begin{array}{c}2.865 \\
(0.880)\end{array}$ & & $\begin{array}{c}2.905 \\
(0.891)\end{array}$ & \\
\hline D & $\begin{array}{c}3.103 \\
(0.787)\end{array}$ & $22.148^{* *}$ & $\begin{array}{c}2.568 \\
(0.822)\end{array}$ & $17.996^{* *}$ & $\begin{array}{c}3.042 \\
(0.749)\end{array}$ & $33.023^{* *}$ & $\begin{array}{c}2.824 \\
(0.865)\end{array}$ & $4.480^{* *}$ & $\begin{array}{c}2.712 \\
(0.872)\end{array}$ & $34.349^{* *}$ \\
\hline E & $\begin{array}{c}3.712 \\
(0.528)\end{array}$ & & $\begin{array}{c}3.119 \\
(0.782)\end{array}$ & & $\begin{array}{c}3.681 \\
(0.447)\end{array}$ & & $\begin{array}{c}3.103 \\
(0.635)\end{array}$ & & $\begin{array}{c}3.474 \\
(0.581)\end{array}$ & \\
\hline SL & $\begin{array}{c}3.580 \\
(0.952)\end{array}$ & $10.091^{* *}$ & $\begin{array}{c}3.041 \\
(0.728)\end{array}$ & $9.568^{* *}$ & $\begin{array}{c}3.520 \\
(0.854)\end{array}$ & $12.394^{* *}$ & $\begin{array}{c}3.200 \\
(0.909)\end{array}$ & $9.795^{* *}$ & $\begin{array}{c}3.196 \\
(1.022)\end{array}$ & $7.590^{* *}$ \\
\hline NSL & $\begin{array}{c}3.151 \\
(0.878)\end{array}$ & & $\begin{array}{c}2.619 \\
(0.856)\end{array}$ & & $\begin{array}{c}2.102 \\
(0.675)\end{array}$ & & $\begin{array}{c}2.788 \\
(0.765)\end{array}$ & & $\begin{array}{c}2.809 \\
(0.806)\end{array}$ & \\
\hline
\end{tabular}

Table 5

Permanent commitment

\begin{tabular}{cccccccc}
\hline Variable & $\mathrm{A}$ & $\mathrm{B}$ & $\mathrm{C}$ & $\mathrm{D}$ & $\mathrm{E}$ & $\mathrm{SL}$ & NSL \\
\hline $\mathrm{SD}$ & 2.150 & 3.278 & 3.289 & 3.205 & 3.462 & 3.402 & 3.224 \\
& $(0.452)$ & $(0.426)$ & $(0.552)$ & $(0.528)$ & 0.515 & $(0.493)$ & $(0.545)$ \\
$\mathrm{F}$ & 0.923 & & & $9.458^{* *}$ & $4.244^{* *}$ & & \\
\hline
\end{tabular}

The other analysis is to measure the relationship between different long-term components and combinations of experience, age and educational level. In Table 6, the first variable represents for those with less than 5 years of job experience ( $5 \mathrm{YJE})$, the second row is for those with 6 to 10 years of job experience (6-10YJE), the third row represents the 11-15YJE and more than 16 years of job experience (16YJE), the fourth row represents the employee with less than 9 years of educational background (LEB), the fifth column is for those with high school knowledge (HSB), the six column is for 14 years of educational background (14EBG), the next one is for people bachelor degree 
(BDEG), those with bachelor and less than 30 years age (B\&30), people with 30-39 and finally the last column represents the employee with 40 to 49 and more than 50 years of ages.

Table 6

Principle component analysis among different independent items

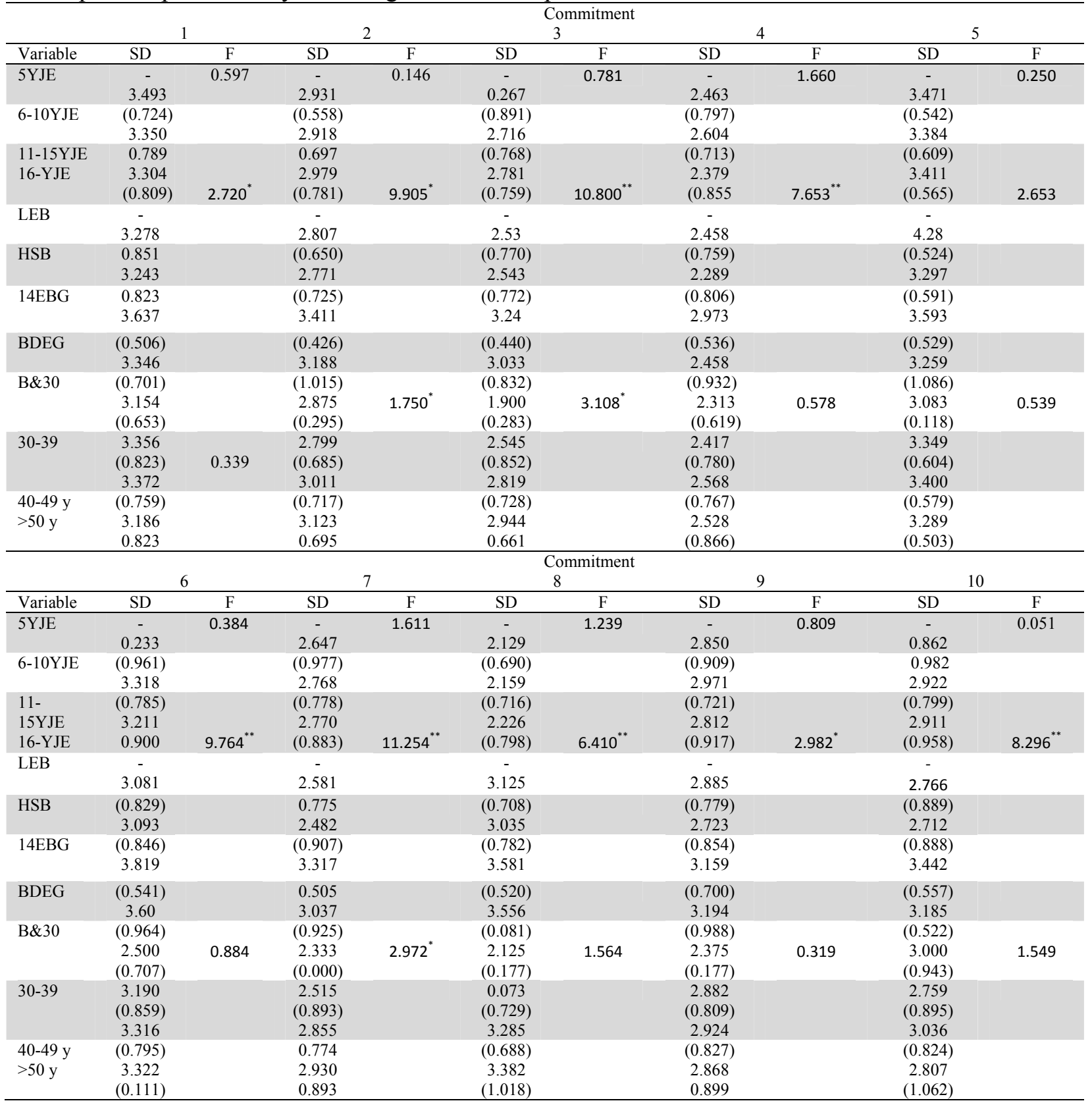

1: Management style, 2: Work identity, 3: Working environment, 4: Job promotion, 5: Employee relationship, 6: Security, 7: Payment, 8: Family, 9: Performance measurement, 10: Environment

Table 7

Permanent commitment

\begin{tabular}{|c|c|c|c|c|c|c|c|c|c|c|}
\hline Variable & $5 \mathrm{YJE}$ & 6-10YJE & $\begin{array}{c}\text { 11-15YJE } \\
16-Y J E\end{array}$ & LEB & HSB & $14 \mathrm{EBG}$ & BDEG & B\&30 & $30-39$ & $\begin{array}{c}40-49 y \\
>50 y\end{array}$ \\
\hline SD & - & $(0.513)$ & $(0.480)$ & - & $(0.521)$ & $(0.567)$ & $(0.465)$ & $(0.522)$ & 3.177 & $(0.561)$ \\
\hline & 3.120 & 2.215 & $\begin{array}{c}3.427 \\
(0.592)\end{array}$ & 3.243 & 3.229 & 3.463 & 2.967 & $\begin{array}{c}2.850 \\
(0.354)\end{array}$ & $\begin{array}{c}(0.459) \\
3.289\end{array}$ & $\begin{array}{c}3.632 \\
(0.574)\end{array}$ \\
\hline F & $4.866^{*}$ & & $3.115^{*}$ & & $4.244^{* *}$ & & & $4.299^{*}$ & & \\
\hline
\end{tabular}


From the results of Table 6 and Table 7, we can understand the impacts of different factors on permanent commitment. Now we can perform a regression analysis on the result to have more detailed results. Table 8 summarizes the results of the implementation of different regression functions.

\section{Table 8}

The results of the implementation of two regression models on permanent commitment

\begin{tabular}{|c|c|c|c|c|}
\hline & \multicolumn{2}{|c|}{ Formula 1} & \multicolumn{2}{|c|}{ Formula 2} \\
\hline & VIF & $\beta(p)$ & VIF & $\beta(p)$ \\
\hline Division of work & 1.555 & $0.185(0.107)$ & 1.834 & $0.101(0.325)$ \\
\hline Position & 1.852 & $-0.047(0.704)$ & 2.014 & $0.141(0.188)$ \\
\hline First grade position & 2.717 & $0.021(0.873)$ & 2.890 & $0.161(0.154)$ \\
\hline Second grade position & 3.876 & $0.035(0.833)$ & 4.213 & $0.240(0.098)$ \\
\hline First grade degree & 1.476 & $-0.125(0.215)$ & 1.612 & $0.030(0.732)$ \\
\hline Second grade degree & 2.383 & $0.036(0.814)$ & 2.654 & $-0.002(0.991)$ \\
\hline Third grade degree & 1.213 & $-0.399(0.058)$ & 1.313 & $-0.383^{*}(0.034)$ \\
\hline First level of age & 22.295 & $0.370(0.342)$ & 23.690 & $0.109(0.741)$ \\
\hline Second level of age & 25.124 & $0.417(0.303)$ & 26.459 & $0.095(0.780)$ \\
\hline Third level of age & 9.924 & $0.734(0.092)$ & 10.421 & $0.407(0.269)$ \\
\hline Style of management & & & 2.094 & $0.040(0.526)$ \\
\hline Position & & & 3.141 & $0.218^{*}(0.011)$ \\
\hline Environment & & & 4.630 & $-0.007(0.940)$ \\
\hline Promotion & & & 3.411 & $-0.026(0.733)$ \\
\hline Relationship & & & 1.546 & $0.038(0-600)$ \\
\hline Security & & & 2.547 & $0.082(0.192)$ \\
\hline Payment & & & 2.020 & $0.110^{+}(0.058)$ \\
\hline Family & & & 2.456 & $0.208^{* *}(0.003)$ \\
\hline Performance measurement & & & 2.692 & $0.011(0.871)$ \\
\hline Working environment & & & 2.945 & $-0.071(0.268)$ \\
\hline Adjusted $R^{2}$ & & $0.129(0.074)$ & & $0.444(0.370)$ \\
\hline Changes in $R^{2}$ & & 0.129 & & 0.315 \\
\hline Changes in $F^{2}$ & & $2.355^{*}$ & & $5.954^{*}$ \\
\hline
\end{tabular}

As we can observe from Table 8, the regression model 2 represents better results compared with the regression model 1. According to the results of the second model, three variables of family, position and payment play important role on permanent confidence of a firm. We have performed another round of interview and questionnaire and the results of our survey are summarized in Table 9.

\section{Table 9}

The summary of our survey for the second round of interview for job satisfaction

\begin{tabular}{clcc}
\hline Rank & Job satisfaction & Frequency & Percentage \\
\hline 1 & Payment & 39 & 25.3 \\
2 & Personal healthcare and life & 27 & 17.5 \\
3 & Environment & 21 & 13.6 \\
4 & Working conditions and its pressure & 11 & 7.1 \\
5 & The style of management & 9 & 5.8 \\
6 & Work environment & 8 & 5.2 \\
7 & Promotion & 8 & 5.2 \\
8 & Job progress & 8 & 5.2 \\
9 & Relationship with other workers & 7 & 4.5 \\
10 & Workshop and learning & 4 & 2.6 \\
11 & Other issues & 4 & 2.6 \\
12 & Safety and Security & 3 & 1.9 \\
13 & Discipline & 2 & 1.3 \\
14 & Performance measurement & 1 & 0.6 \\
\hline Sum & & 154 & 100 \\
\hline
\end{tabular}


It is clear from the results of our interview that payment, personal healthcare, environment, working conditions and its pressure are considered as the most important issues. Other factors such as job promotion, job progress, etc. are considered as the secondary important issues.

Our detailed interview revealed that most of the workers heavily depend on their payment to cover their expenses such as food, rent and their children educational expenses. The people who participated in our survey believed that a healthy family with good income represents an ideal job satisfaction.

The other issue, which affects job satisfaction, was the pressure on remaining workers after mass layoff. This issue has already been discussed in other relative articles (Hrebiniak \& Alutto, 1972; Rousseau, 1995; Maierhofer et al., 2002). They believed the management not only expect more work but also request them to get additional degrees to continue their job in their present position. In addition, workers believed that work reduction had been an issue for a long time and there were many cases where workers were sent to some places, which was far from where they resided. They claimed there had been many complains about these actions but no changes were made. They workers complained that the working conditions had been changes and management team used tough working conditions, which created motivation among many workers to apply for early retirement.

\section{Conclusions}

In this paper, we have presented an empirical study to investigate the impact of different factors on job satisfaction and workers' long-term commitments. The present study of this paper designed a questionnaire and used principal component analysis to find the most important issues affecting workers fidelity after a layoff happens. The study was implemented for a real-world case study of detergent producer in Iran. The results indicated that payment, personal healthcare, environment, working condition and its pressure were among the most important issues affecting long-term commitment. In addition, there were other factors such as job promotion; job progress; etc., which were considered as the secondary important issues.

\section{References}

Baron, J.N. and Kreps, D.M. (1999). Strategic Human Resources: Frameworks for General Management. John Wiley \& Son, Inc., NK.

Beam, H.H. (1997). Survivors: how to keep your best people on board after downsizing. The Academy of Management Executive, 11(2), 92-94.

Brockner, J., Wiesenfeld, B., Stephen, J., Hurley, R., Grover, S., Reed, T. and DeWitt, R. L. (1997). The effects on layoff survivors of fellow survivors' layoff reactions. Journal of Applied Social Psychology, 27, 835-863.

Cameron, K.S. (1994). Strategies for successful organizational downsizing. Human Resource Management, 33(2), 189-211.

Cascio, W.F. (1993). Downsizing: what do we know? What have we learned? Academy of Management Executive, 7(1), 95-106.

Cronbach, L. J. (1951). Coefficient alpha and the internal structure of tests. Psychometrika, 16(3), 297-334.

Delery, J.E., \& Shaw, J.D. (2001). The strategic management of people in work: review, synthesis and extension. Research in Personnel and Human Resources Management, 20,165-197.

Eisenberger, R., Fasolo, P., \& Davis-LaMastro, V. (1990). Perceived organizational support and employee diligence, commitment, and innovation. Journal of Applied Psychology, 75, 51-59.

Fisher S.R., \& White M.A. (2000). Downsizing in a learning organization: are there hidden cost?. Academy of Management Review, 25(1), 224-251. 
Greenhalgh, L., Lawrence, A.T., \& Sutton, R.L. (1988). Determinants of workforce reduction strategies in declining organization. Academy of Management Review, 13(2), 145-161.

Hair, J.F., Anderson, R.E., Tathan, R.L., \& Black, W.C. (1998). Multivariate Data Analysis, $5^{\text {th }}$ ed., Prentice Hall, New Jersey.

Herzberg, F. (2003) One more time: How do you motivate employees?. Harvard Business Review, 81(1), 87-95.

Hirschman, C. (2001). The kindest cut. Human Resource Magazine, 46(4), 48-53.

Hoppock, R. (1935). Job Satisfaction, Harper \& Brother, New York.

Hrebiniak, L.G., \& Alutto, J.A. (1972). Personal and role related factors in the development of organizational commitment. Administrative Science Quarterly, 17, 555-573.

Likert, R. (1932). A Technique for the Measurement of Attitudes. Archives of Psychology, 140, 1-55.

Maierhofer, N.I., Kabanoff, B., \& Griffin, M.A. (2002). The influence of values in organizations: linking values and outcomes at multiple levels of analysis. International Review of Industrial and Organizational Psychology, 17, 217-263.

Mckee-Ryan, F.M., \& Kinicki, A.J. (2002). Coping with job loss: a life-facet perspective. International Review of Industrial and Organizational Psychology, 17, 1-29.

McKinley, W., Sanchez, C.M., \& Schick, A.G. (1995). Organizational downsizing: constraining, cloning, learning. The Academy of Management Executive, 9(3), 32-44.

McKinley, W., Zhao, J., \& Rust, K.G. (2000). A sociocognitive interpretation of organizational downsizing. Academy of Management Review, 25(1), 227-243.

McMaster, M. (2002). The post-layoff blues. Sales and Marketing Management, 154(4), 4, 26.

Meyer, J.P., Bobocel, D.R., \& Allen, N.J. (1991). Development of organizational commitment during the first year of employment: a longitudinal study of pre- and post- entry influence. Journal of Management, 17, 717-733.

Millward, L.J., \& Brewerton, P.M. (2002). Psychological contracts: employee relations for the twenty-first century?. International Review of Industrial and Organizational Psychology, 15, 161.

Mitchell, T.R., \& Lee, T.W. (2001). The unfolding model of voluntary turnover and job embeddedness: foundations for a comprehensive theory of attachment. Research in Personnel and Human Resources Management, 23, 189-246.

Naumann, E.S., Bies, J.R., \& Martin, L.C. (1995). The roles of organizational support and justice during a layoff. Academy of Management Journal, Special issue, 89-95.

Prahalad, C.K., \& Hamel, G. (1990). The core competence of the corporation. Harvard Business Review, 90(3), 79-91.

Rigby, D. (2002). Look before you lay off. Harvard Business Review, 80(4), 20-21.

Rousseau, D.M. (1995). Psychological Contracts in Organizations: Understanding Written and Unwritten Agreements, Sage, London \& New York.

Seal, F.E., \& Knight, P.A. (1988). Industrial.Organizational Psychology: Science \& Practice, Brooks.Cole, Pacific Grove of California.

Shah, P.P. (2000). Network destruction: the structural implications of downsizing. Academy of Management Journal, 43(1), 101-112.

Smith, P.C., Kendall, L., \& Hulin, C.L. (1969). The Measurement of Satisfaction in Work and Retirement, Rand McNally, Chicago.

Sun, B-C., \& Yeh, Y-C. (1996). The study of the impact of downsizing on remaining employees' organizational behaviors. Personnel Monthly, 23(2), 26-38.

Wiener, Y. (1982). Commitment: a behavior approach to job involvement. Journal of Vocational Behaviour, 10, 47-52.

Wright, P.M., \& McMahan, G.C. (1992). Theoretical perspectives for strategic human resource management. Journal of Management, 18(2), 295-320.

Wright, P.M., \& Snell, S.A. (1998). Toward a unifying framework for exploring fit and flexibility in strategic human resource management. Academy of Management Review, 23(4), 756-772. 